\title{
PELATIHAN TEKNOLOGI PEMBELAJARAN: BLENDED LEARNING UNTUK GURU DI SMPN 12 TARAKAN
}

\author{
Enditiyas Pratiwi ${ }^{1 *}$, Woro Kusmaryani ${ }^{2}$, Fadhlan Muchlas Abrori ${ }^{3}$ \\ $1^{*}, 2,3$ Universitas Borneo Tarakan, Tarakan, Indonesia \\ enditivasp@borneo.ac.id \\ worokusmaryani@borneo.ac.id \\ fadhlan1991@gmail.com
}

\begin{abstract}
Abstrak: Semester Gasal 2021/2022 beberapa sekolah di Kota Tarakan sudah mulai melaksanakan pembelajaran dengan kondisi pertemuan tatap muka (PTM) terbatas. Oleh karena itu, penting untuk melakukan kegiatan terkait dengan pemantapan guru dalam melaksanakan PTM terbatas, khususnya penggunaan teknologi pembelajaran sehingga mendukung pelaksanaan blended learning. Kegiatan dilaksanakan dengan luring dan daring, di mana kegiatan luring dilakukan langsung dalam bentuk praktik sehingga guru dapat memahami langkah-langkah dalam penggunaan teknologi pembelajaran (pixton, seesaw, dan quiziz:). Sedangkan kegiatan daring untuk memfasilitasi guru dalam melakukan simulasi praktik penggunaan pixton, seesaw, dan quiriz:. Kegiatan pengabdian yang dilaksanaan diikuti dengan baik oleh guru terbukti dengan kemampuan guru dalam melakukan praktik secara mandiri terhadap ketiga platform yang sudah disajikan meskipun belum mengeksplorasi fitur platform secara lebih mendalam.
\end{abstract}

Kata Kunci: Blended Learning, Pixton, Seesaw, Quirizz.

\section{Pendahuluan}

Pengembangan profesional guru adalah segala jenis upaya pendidikan berkelanjutan bagi pendidik. Ini adalah salah satu cara guru dapat meningkatkan keterampilan mereka dan pada gilirannya, meningkatkan hasil belajar siswa. Belajar dapat berlangsung dalam suasana formal atau informal. Pengaturan formal termasuk konferensi, kursus, seminar, retret dan lokakarya. Peluang informal untuk pengembangan profesional guru termasuk penelitian atau investigasi independen, inisiatif pembelajaran sebaya atau bahkan hanya mengobrol dengan rekan kerja di ruang staf. Pengembangan profesional untuk guru terjadi di sejumlah tingkatan yang berbeda: di seluruh kabupaten, di antara guru di sekolah tertentu, atau bahkan di kelas atau secara individu. Jelas bahwa guru yang baik lebih baik dalam mengajar siswa secara efektif. Ketika guru memiliki akses ke peluang belajar berkelanjutan dan sumber daya pengembangan profesional, mereka lebih siap untuk menjadi guru yang baik — terutama jika siswa mereka memiliki kebutuhan belajar atau berprestasi di bawah atau di atas tingkat kelas (Indrawati \& Octoria, 2016).

Menurut sebuah penelitian, sepertiga guru meninggalkan profesinya dalam waktu tiga tahun, dan setengah dari guru keluar dalam waktu lima tahun. Meskipun ada sejumlah penjelasan untuk statistik ini, tidak ada pengganti untuk pengalaman langsung dalam hal pengajaran di kelas yang efektif. Guru menghabiskan seluruh karir mereka mengembangkan keterampilan baru dalam 
menanggapi tantangan yang mereka hadapi, tetapi guru baru belum memiliki kesempatan untuk membangun sumber daya mereka sendiri. Pengembangan profesional dapat membantu guru baru dan berpengalaman mengembangkan keterampilan yang mereka butuhkan untuk merasa percaya diri di kelas. Pengembangan profesional yang efektif membantu guru membentuk pembelajaran sepanjang karir (Rahman, 2021).

Peluang pengembangan profesional guru yang bijaksana dan terarah meningkatkan hasil siswa dan mendorong pola pikir yang berkembang. Pengembangan profesional guru mendorong guru untuk menjadi peserta aktif dalam pembelajaran mereka sendiri, dan memastikan bahwa siswa dan guru sama-sama bersemangat untuk belajar. Ketika memberikan pembelajaran dan dukungan untuk guru, mengomunikasikan bahwa komunitas sekolah menghargai pekerjaan yang mereka lakukan dan ingin mereka tumbuh. Kurangnya sumber daya pengembangan profesional untuk guru dapat mengecilkan hati. Ini mengomunikasikan bahwa tidak ingin berinvestasi dalam kualitas pengajaran dan lebih menekankan pada guru untuk mengembangkan keterampilan mereka sendiri (Rahman, 2021).

Pengembangan professional guru dapat dilakukan salah satunya dalam hal peningkatan kemampuan penggunaan teknologi yang digunakan dalam pembelajaran. Pasca menurunnya angka Covid-19 di beberapa wilayah di Indonesia, pembelajaran direncanakan menggunakan metode tatap muka terbatas dengan menggunakan metode bybrid learning atau blended learning. Pembelajaran campuran menggabungkan yang terbaik dari dua lingkungan pelatihan-pelatihan kelas tatap muka tradisional dan eLearning berteknologi tinggi. Dengan mencakup semua dasar, Anda dapat melibatkan semua jenis pelajar-mereka yang belajar lebih baik dalam lingkungan terstruktur yang mencakup interaksi tatap muka dengan instruktur, dan tipe mandiri yang belajar lebih baik dengan pelatihan berbasis komputer semi-otonom (Deng et al., 2021).

Sementara ruang kelas menawarkan kesempatan untuk bermain peran dengan umpan balik tatap muka langsung, pembelajaran online menawarkan pembelajaran mandiri yang dipersonalisasi dengan komponen eLearning/mLearning yang cocok untuk media interaktif seperti pengembangan keterampilan, permainan, video, tutorial, kuis, dan komponen media sosial, semuanya dapat diakses dari halaman beranda pelajar di Learning Management System (LMS)—dan dapat diakses dari smartphone atau tablet pelajar (Tamim, 2020).

Pembelajaran campuran mempertimbangkan setiap jenis pelajar, apakah mereka lebih suka kelas tradisional yang sudah dikenal, lebih suka belajar online, atau mencoba campuran keduanya. Tanpa batasan ruang kelas atau kursus online, pembelajaran campuran menggunakan berbagai metodologi sehingga konten dapat disesuaikan dengan pelajar dan dioptimalkan untuk materi pelajaran. Meskipun tidak semua pelatihan tatap muka mudah diterjemahkan ke konten digital, konten yang ada dapat direkayasa ulang untuk pengiriman online dengan cara yang melengkapi pelatihan yang ada (Rozitis, 2017).

Pembelajaran campuran menggunakan teknologi online dan offline secara bersamaan, memungkinkan instruktur untuk dengan cepat mengadopsi tren dan modalitas pembelajaran terbaru ke dalam kurikulum. Instruktur juga dapat menggunakan fitur pelaporan bawaan di sebagian besar program perangkat lunak LMS untuk wawasan yang lebih dalam dan didorong oleh 
data tentang kemajuan dan kesuksesan siswa. Bagi pelajar, pembelajaran campuran juga menawarkan kesempatan unik untuk berdiskusi, membuat model, dan mempraktikkan keterampilan baru mereka di tempat yang aman, sehingga mereka tidak hanya menonton atau mendengar-mereka melakukan. Dengan menerapkan pengetahuan baru segera setelah mereka meninggalkan kelas fisik atau virtual, pelajar mempertahankan apa yang telah mereka pelajari (Baldwin \& Ching, 2021).

Blended learning adalah pengalaman interaktif dalam setiap arti kata. Peserta didik memperkuat pelajaran offline dengan berlatih online melalui berbagai media konten yang berbeda, masing-masing disesuaikan dengan gaya belajar tertentu. Pembelajar dapat memilih jenis konten yang ingin mereka gunakan untuk berinteraksi, mempraktikkan apa yang mereka pelajari, dan berkomunikasi dengan instruktur dan pelajar lain kapan saja dan di perangkat apa pun. Pengalaman komunitas membuat peserta didik tetap terlibat dan memberi tahu guru tentang kemajuan mereka dan bidang yang membutuhkan perhatian lebih (Barneva et al., 2017).

Blended learning memerlukan kemampuan guru dalam menggunakan teknologi yang dapat digunakan dalam pembelajaran. Hal ini juga masih menjadi permasalahan yang dihadapi guru yakni para guru yang mencoba mengintegrasikan teknologi ke dalam kelas mereka adalah kurangnya pengetahuan dan pemahaman tentang cara menggunakan teknologi, atau ketidaknyamanan saat menggunakannya. Guru yang memiliki masalah ini juga berjuang dengan disediakannya sumber daya pengembangan profesional untuk membantu mereka memperoleh pengetahuan dan keakraban untuk memperkenalkan teknologi secara andal dan efektif. Program Pelatihan Guru yang dilengkapi dengan pelatihan menyeluruh tentang cara terbaik bagi guru untuk menggunakan teknologi ini untuk mendukung pembelajaran digital di kelas mereka. Guru dapat terhubung dengan instruktur untuk dukungan dan bantuan berkelanjutan dalam menggunakan teknologi pembelajaran, serta mengakses banyak pilihan sumber daya guru yang berisi gagasan tentang cara mengintegrasikan teknologi ke dalam kelas dan cara mendapatkan hasil maksimal dari guru (Sung et al., 2016).

Dari pemaparan di atas, pusat studi pendidikan, kesehatan, dan kesetaraan gender berupaya untuk dapat membantu guru-guru dalam mempersiapkan pembelajaran tatap muka terbatas dengan menggunakan metode blended learning dalam satu Program Kemitraan bagi Masyarakat (PKM) yang berjudul "Pelatihan Teknologi Pembelajaran: Blended Learning untuk Guru di SMPN 12 Tarakan, Kalimantan Utara.

\section{Metode Pelaksanaan}

Pelaksanaan kegiatan dilakukan di SMPN 12 Kota Tarakan, Kalimantan Utara pada tanggal 8-11 Desember 2021. SMPN 12 Tarakan dipilih sebagai mitra kegiatan pengabdian karena merupakan sekolah baru sehingga masih memerlukan pendampingan untuk mendukung proses pembelajaran. Kegiatan ini mengakomodir semua mata pelajaran karena berfokus pada penggunaan teknologi pembelajaran sehingga dapat diikuti oleh 22 guru dengan berbagai latar belakang bidang mata pelajaran. 

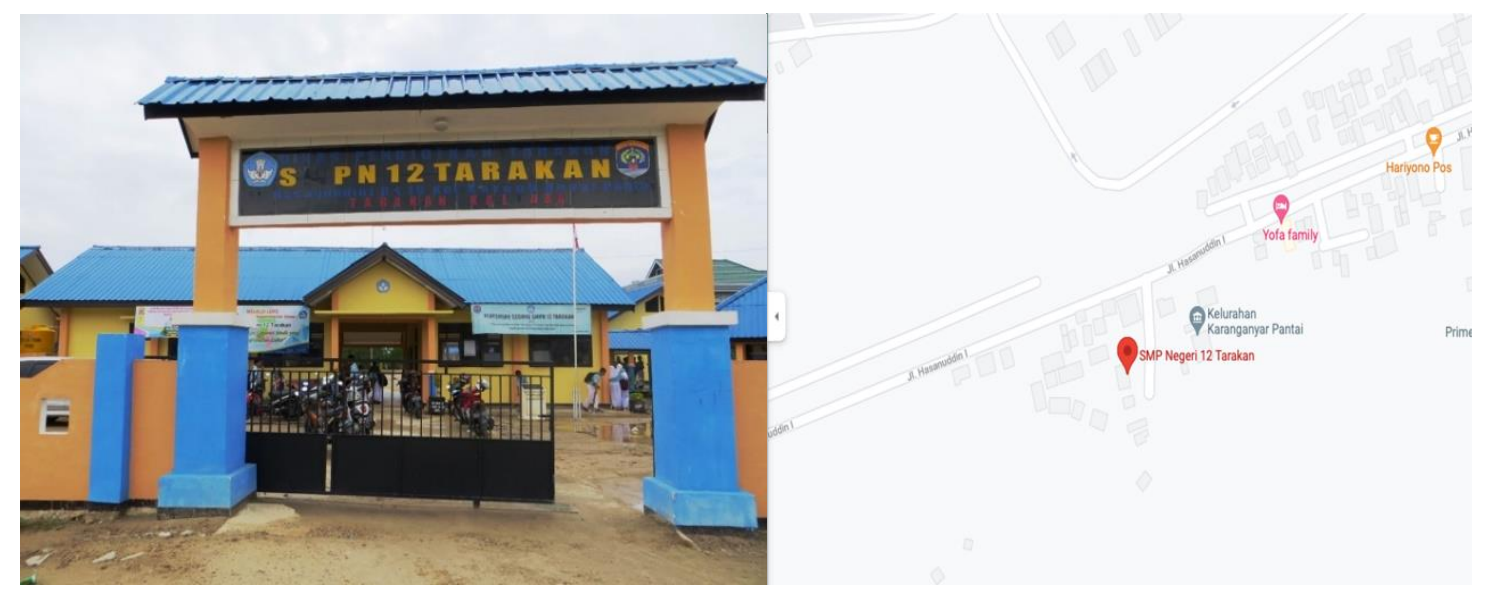

Gambar 1. Lokasi Pelaksanaan Pelatihan (SMPN 12 Tarakan)

Kegiatan dibagi dalam 3 tahapan utama, yaitu: tahap persiapan, tahap pelaksanaan, dan evaluasi. Tahap pelaksanaan dan evaluasi dilakukan selama empat hari, dan terbagi menjadi dua sesi, yaitu sesi luring dan daring. Sesi luring dilakukan melalui metode penyajian materi dan dilanjutkan praktik langsung sehingga guru-guru dapat mengetahui langkah-langkah penggunaan teknologi pembelajaran. Pada sesi luring juga dibagi menjadi tiga bagian, yaitu materi Pixton, Quirizz dan Seesaw.

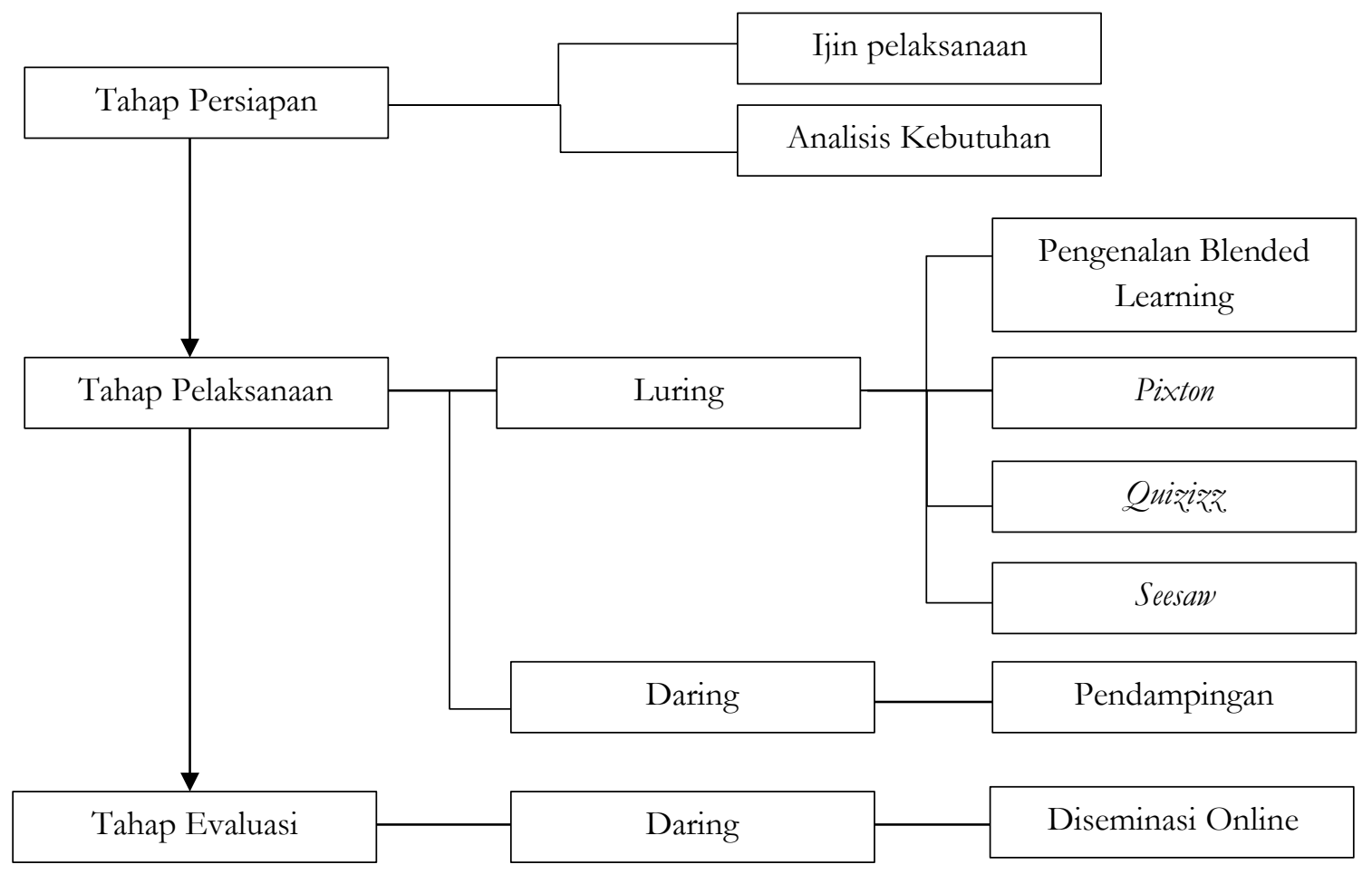

Gambar 2. Tahapan Pelaksanaan Kegiatan 
Indikator keberhasilan diukur pada tahapan evaluasi. Indikator dalam kegiatan ini adalah guru-guru mampu membuat komik digital, kuis dengan berbagai tipe pertanyaan dan memasukkan komik digital dan kuis tersebut pada platform Seesaw. Kegiatan guru dilakukan secara mandiri dan didampingi melalui WAG (WhatApps Group). Pendampingan secara daring di hari terkahir kegiatan diminta tiga guru sebagai perwakilan untuk menampilkan hasil kerjanya melalui diseminasi online untuk mendapat masukan (feedback) lebih lanjut dari tim pengabdian kepada masyarakat.

\section{Hasil dan Pembahasan}

\section{Tahap Persiapan}

Tahap persiapan dilakukan dengan kunjungan ke SMPN 12 Tarakan menemui Kepada Sekolah. Maksud dari kunjungan adalah untuk menanyakan kesedian pihak sekolah untuk terlibat dalam kegiatan pengabdian. Selain itu, kunjungan tersebut dimaksudkan untuk melakukan analisis kebutuhan terhadap teknologi pembelajaran apa yang dibutuhkan oleh guru-guru sehingga dapat mendukung proses blended learning. Selain melakukan kunjungan juga dilakukan koordinasi melalui What Apps untuk mendukung kelancaran pelaksanaan kegiatan pengabdian.

Bagian terpenting dalam tahapan ini adalah analisis kebutuhan teknologi pembelajaran yang diperlukan oleh guru dalam upaya mendukung pelaksanaan blended learning. Analisis kebutuhan merupakan upaya agar pelaksanaan kegiatan lebih terarah dan terfokus terhadap permasalahan yang dihadapi sekolah (Stufflebeam \& Shinkfield, 1985). Melalui analisis kebutuhan juga bias ditentukan prioritas terbuka terhadap kebutuhan (Nasrulloh \& Ismail, 2017). Hasil dari analisis kebutuhan di SMPN 12 didapatkan data bahwa guru masih belum memahami konsep dari blended learning, dan juga jenis modelnya. Selain itu, guru juga masih belum memiliki keterampilan yang mencukupi dalam mengembangkan media digital dalam mendukung pelaksanaan blended learning. Hasil analisis kebutuhan menyatakan bahwa guru hanya mengetahui segelintir platform atau website yang digunakan selama pembelajaran daring seperti Google classroom dan Google Form, sebagai sarana dalam kelas virtual dan pelaksanaan evaluasi.

Berdasarkan hasil analisis kebutuhan ini, tim pengabdian bersama dengan Kepala Sekolah merancang beberapa kegiatan sebagai upaya peningkatan pengetahuan dan keterampilan guru dalam pengelolaan blended learning. Hasil dari perancangan kegiatan dirumuskan beberapa hal sebagai berikut:

a. Guru memerlukan pengetahuan tentang konsep dasar blended learning dan pelaksanaannya (model-model dalam blended learning).

b. Guru memerlukan keterampilan dalam pengembangan media visual digital sebagai media pendukung dalam pelaksanaan blended learning.

c. Guru memerlukan keterampilan dalam pengelolaan dan pengembangan platform/website dalam evaluasi pembelajaran

d. Guru memerlukan keterampilan dalam pendesainan, pengelolaan dan pengembangan virtual classroom selain Google Classroom dalam rangka memperkaya keterampilan guru terkait virtual classroom. 
Permasalahan yang terjadi di SMPN 12 terkait pengetahuan dan keterampilan guru dalam blended learning sebenarnya banyak dialami oleh guru, tidak hanya di Indonesia akan tetapi di seluruh dunia. Permasalahan blended learning banyak terjadi karena kurangnya pengetahuan guru dalam perkembangan teknologi informasi (Mozelius, 2017). Setidaknya dalam beberapa penelitian terdapat 5 aspek yang menjadi permasalahan dalam blended learning, baik dari sisi teknologi, instruksi, technical support, ukuran kelas, dan kolaborasi (Alvarez Jr, 2020).

Hasil dari permasalahan tersebut kemudian diturunkan dalam bentuk kegiatan yang akan dilaksanakan pada tahap pelaksanaan. Rincian kegiatan tersebut dapat terlihat pada bagian metode yang tergambar pada Gambar 2. Kegiatan dimulai dengan pengenalan blended learning, dan dilanjutkan dengan pengenalan jenis platform/website dalam mendukung kegiatan tersebut yang terdiri dari Pixton (untuk media visual digital dalam bentuk komik), Quizizz (untuk evaluasi), dan Seesaw (untuk virtual classroom)

\section{Tahap Pelaksanaan}

Pelaksanaan kegiatan pengabdian berlangsung selama empat hari, di mana satu hari dengan metode luring atau tatap muka dan tiga pertemuan dilakukan dengan metode daring atau tatap maya. Pada metode luring dibagi menjadi empat bagian, yang pertama adalah pemaparan singkat terkait dengan blended learning. Pengenalan blended learning penting untuk guru, karena model dalam penerapannya sangat berbeda dengan pembelajaran tatap muka. Beberapa peneliti menyatakan bahwa lemahnya pengetahuan guru terkait blended learning berdampak pada tidak maksimalnya proses pembelajaran blended learning di dalam kelas (Wong et al., 2014). Beberapa juga melaporkan kurangnya pengetahuan guru tentang blended learning berdampak pada ketidakpahaman siswa dalam mengikuti alur tahapan pada model-model blended learning (Hofmann, 2006). Pemaparan singkat ini secara garis besar memberikan gambaran jenis model blended learning yang bias digunakan oleh guru, sehingga nantinya guru bisa merancang media apa yang bisa dikembangkan dan diimplementasikan dalam model yang dipilih.

Selanjutnya, guru diperkenalkan dengan media komik digital untuk dapat disajikan kepada siswa dalam blended learning. Pembuatan komik digital menggunakan Pixton yang berbasis web dipilih untuk dibahas secara detail karena relatif lebih mudah dalam pengaplikasiannya sehingga cocok untuk pemula. Guru dibimbing melalui praktik langsung bagaimana membuat akun pada Pixton dan membuat komik digital sederhana disesuaikan dengan materi mata pelajarannya masing-masing. Pixton sebagai platform yang menyediakan akses dalam pembuatan komik digital memiliki tingkat flesibilitas yang tinggi, dimana pengguna bisa menyesuaikan karakter (baik gestur dan mimik wajah), latar belakang dan dialog dengan bebas (Gaby, 2012; Meyers, 2014). Fleksibilitas yang tinggi menjadikan website ini banyak digunakan oleh pengajar dan peneliti dalam penyampaian materi pelajaran dan mendapatkan respon baik dari siswa dan tingkat keefektifan yang tinggi (Cabrera et al., 2018). 


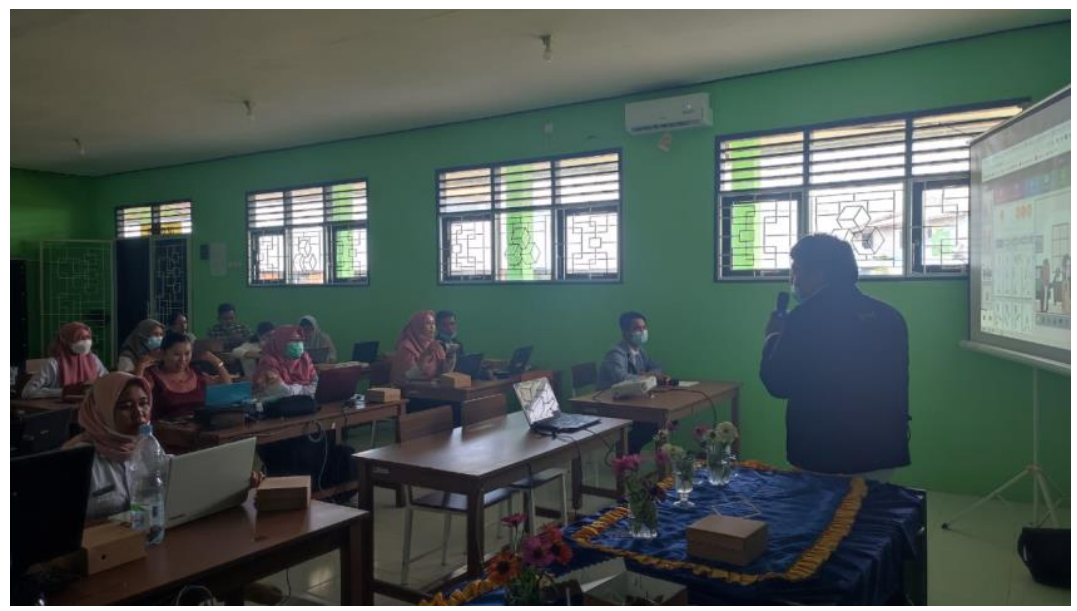

Gambar 3. Pemaparan Blended Learning dan Pixton

Kemudian pada bagian ketiga adalah pemaparan singkat bagaimana mengevaluasi pembelajaran dalam proses blended learning, disajikan beberapa platform yang dapat mendukung proses evaluasi pembelajaran tersebut. Namun, secara detail dibahas terkait dengan penggunaan Quiziz: Pemilihan penggunaan Quizizz karena dapat dilakukan secara realtime sehingga dianggap paling sesuai untuk proses blended learning. Guru dibimbing melalui praktik langsung bagaimana membuat akun pada Quizizz dan membuat beberapa soal dengan berbagai jenis pertanyaan (pilihan ganda, isian singkat, dan sebagainya) disesuaikan dengan materi mata pelajarannya masing-masing. Sebagai platform yang digunakan sebagai bahan evaluasi pembelajaran, Quizizz juga banyak digunakan dalam kegiatan gamifikasi di kelas (Göksün \& Gürsoy, 2019). Tidak jarang juga platform ini digunakan secara luas sebagai bahan survey atau poling sebagai sarana apersepsi di awal pembelajaran atau ice breaking di pertengahan pembelajaran (Chaiyo \& Nokham, 2017; Zhao, 2019). Fleksibilitas dan multi fungsi inilah yang menjadi dasar tim pengabdian mengenalkan platform ini sebagai salah satu platform yang bisa digunakan dalam evaluasi pada blended learning.

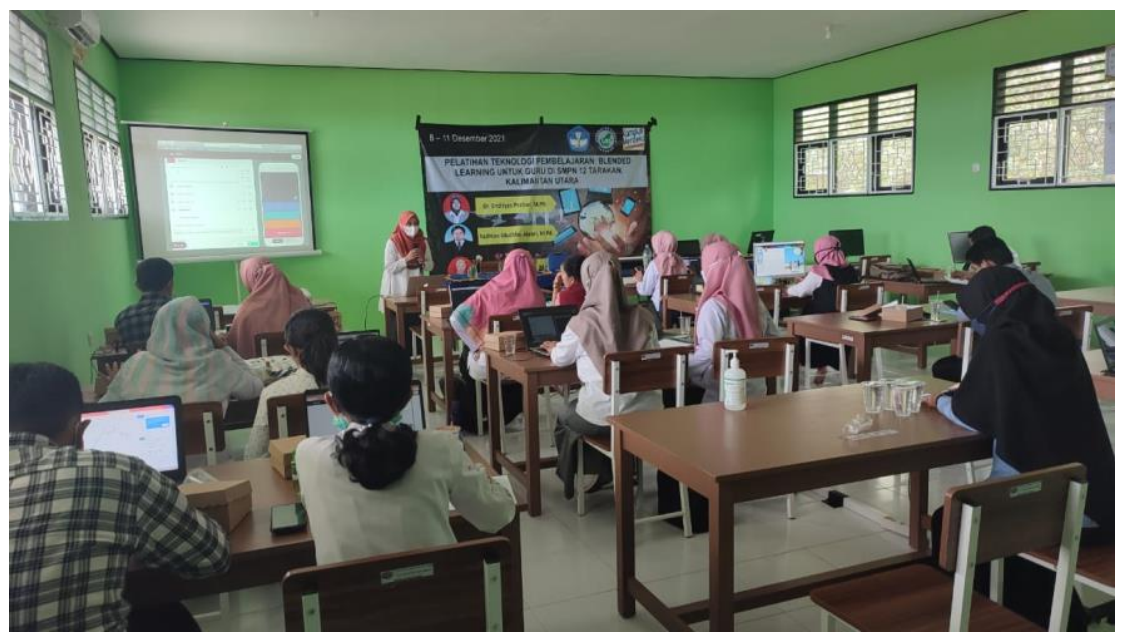

Gambar 4. Pemaparan Materi Quriž

Selanjutnya pada bagian keempat adalah penyajian Seesaw sebagai alternatif penggunaan virtual classroom. Seesaw dipilih karena dapat menjalin komunikasi selain kepada siswa juga kepada orang tua siswa sehingga dalam proses blended learning orang tua siswa juga dapat mengontrol kegiatan 
pembelajaran siswa bersama guru (Bogveradze \& Mardaleishvili, 2021). Guru dibimbing melalui praktik langsung bagaimana membuat akun pada Seesaw dan mencoba berbagai fitur yang tersaji pada menu Seesaw tersebut. Walaupun Seesaw masih jarang digunakan dalam proses pembelajaran di Indonesia, banyak penelitian di luar Indonesia yang menggunakannya untuk proses pembelajaran karena sifatnya yang lebih fleksibel dengan fitur sederhana dan tampilan desain minimalis yang mudah dimengerti oleh guru dan siswa (Holder \& Mills, 2020).

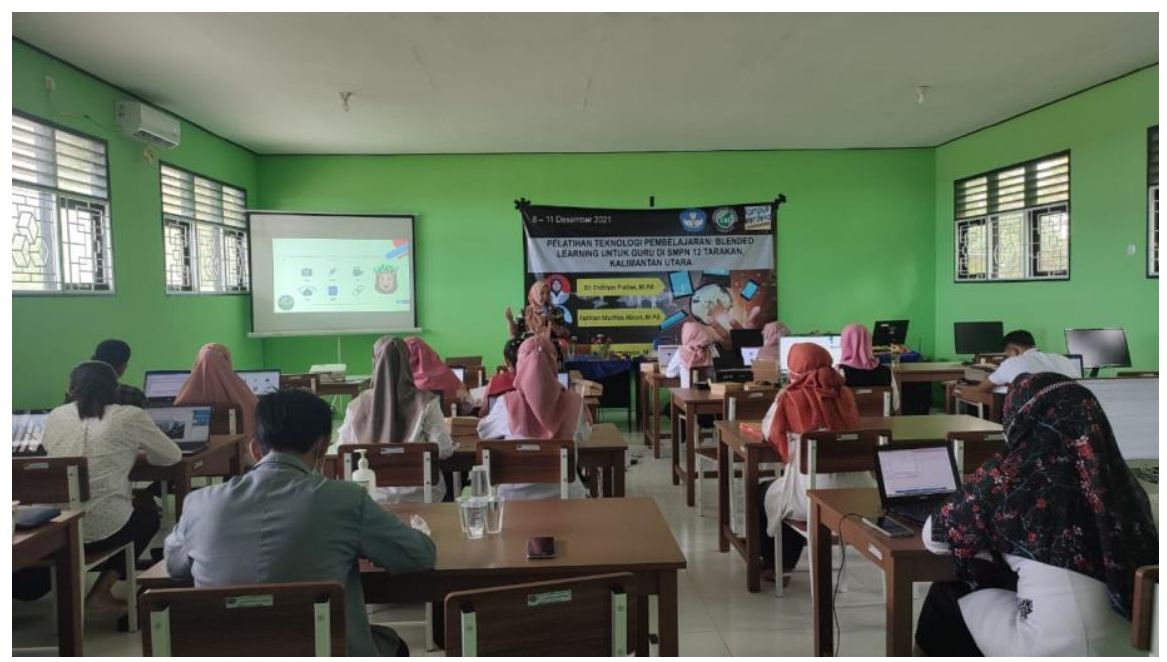

Gambar 5. Pemaparan Materi Seesaw

\section{Tahap Evaluasi}

Tahap evaluasi dilakukan pada hari terakhir kegiatan dan dilaksanakan secara daring atau tatap maya menggunakan platform room meeting. Pada tahap evaluasi ini, perwakilan tiga guru melakukan presentasi hasil kerja terhadap penggunaan teknologi pembelajaran. Guru perwakilan sudah mampu membuat komik digital menggunakan Pixton dan disajikan secara baik dan lengkap sesuai dengan materi yang diajarkan. Secara garis besar guru sudah bisa menggunakan fitur utama dalam Pixton, seperti penambahan karakter dalam satu kolom gambar, bahkan beberapa guru melakukan improvisasi cerita dengan memasukkan lebih dari 3 karakter dalam 1 kolom. Hal lain yang juga telah diterapkan oleh guru adalah dengan mengubah fokus gambar. Guru menggunakan variasi fokus, baik untuk gambar jarak jauh, menengah dan dekat. Penggunaan variasi fokus ini baik untuk menekankan beberapa bagian komik yang memerlukan tampilan secara detail dari gestur dan mimik wajah karakternya. Detail fokus juga memberikan dinamika terkait dialog dalam cerita sehingga alur cerita cenderung variatif dan tidak membosankan.

Beberapa hal bisa ditingkatkan berdasarkan hasil feedback dari tim pengabdian, terutama eksplorasi guru pada Pixton perlu diperdalam lagi. Guru masih kurang mengekplor terkait variasi gestur, dan variasi pakaian/ kostum dari tokoh dalam Pixton. Hal lainnya yang ditekankan adalah kurang mendalamnya cerita yang dibangun oleh guru, dan juga hubungan alur cerita dan konsep materi yang akan diajarkan masih ada beberapa yang tidak terkoneksi dengan baik. Namun, secara keseluruhan hasil dari komik yang dikembangkan oleh guru sudah baik dan memiliki alur yang kuat serta penjabaran konsep yang baik. 


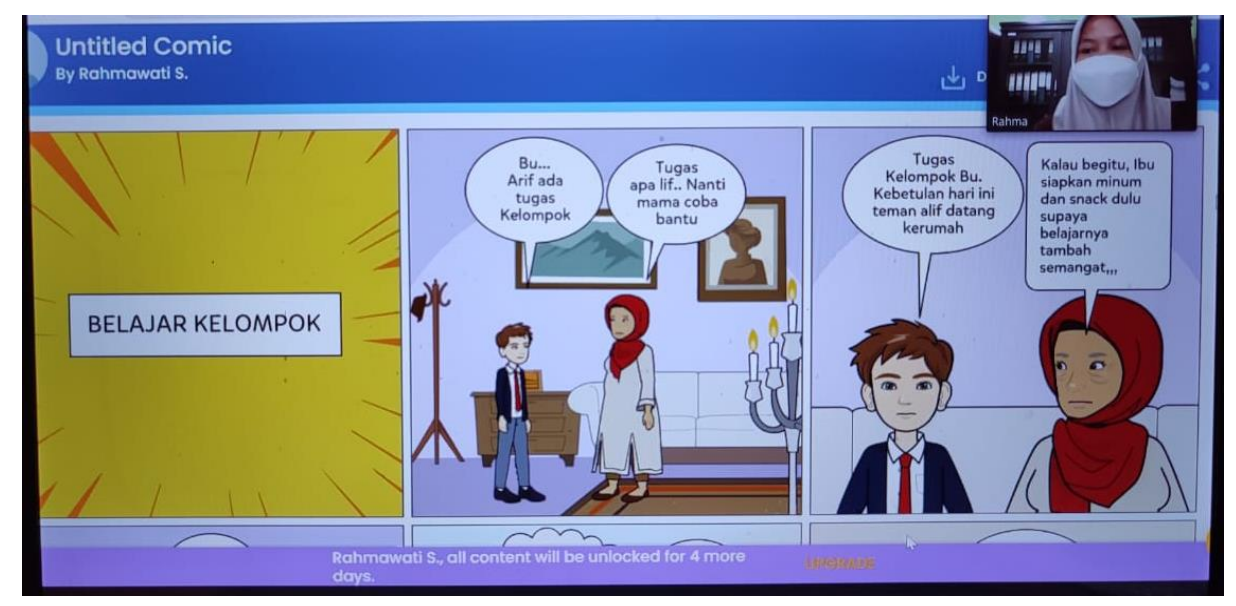

Gambar 6. Komik Digital Hasil Kerja Guru

Guru perwakilan juga sudah bisa menggunakan Quiziz: dengan fitur pertanyaan yang beragam dan mampu menjalankan Quizizz tersebut secara realtime dan diikuti oleh beberapa peserta kegiatan pelatihan. Dalam proses diseminasi guru menerapkan beberapa jenis evaluasi yang merupakan fitur utama Quiriž seperti pilihan ganda, jawaban singkat, dan poling. Beberapa feedback dari tim pengabdian masyarakat kepada guru terkait pengembangan Quizizz adalah dengan mengekplorasi lebih jauh fitur lainnya, seperti pengintegrasian soal dengan presentasi, sehingga penggunaan Quirizz tidak hanya dimanfaatkan sebagai evaluasi akhir, namun juga bisa digunakan pada awal dan pertengahan pembelajaran.

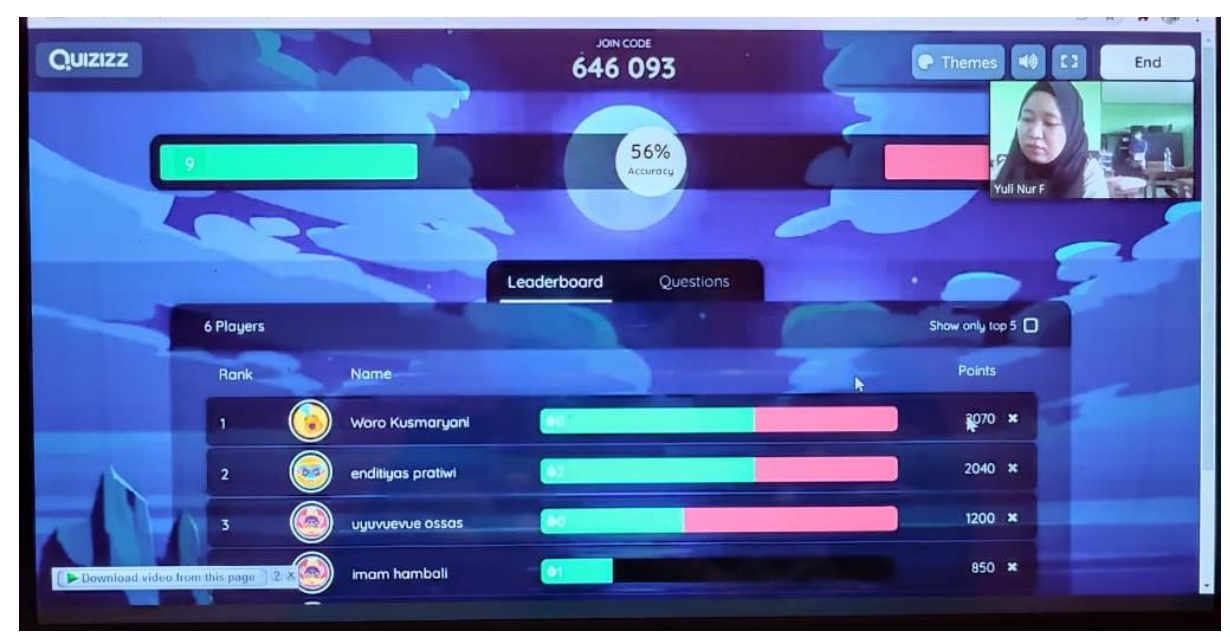

Gambar 7. Quizizz Hasil Kerja Guru

Diseminasi terakhir untuk jenis platform/website yang digunakan untuk blended learning adalah Seesaw. Guru perwakilan juga sudah bisa menggunakan Seesaw dengan berbagai fitur yang terdapat di menunya dan disajikan secara baik sesuai dengan materi pelajarannya. Namun karena keterbatasan waktu desain kelas virtual masih belum lengkap sehingga guru hanya menampilkan contoh kelas virtual untuk satu materi saja. Guru juga telah bisa menyematkan berbagai media baik berupa gambar, dan video dalam kelas virtual pada Seesaw. 


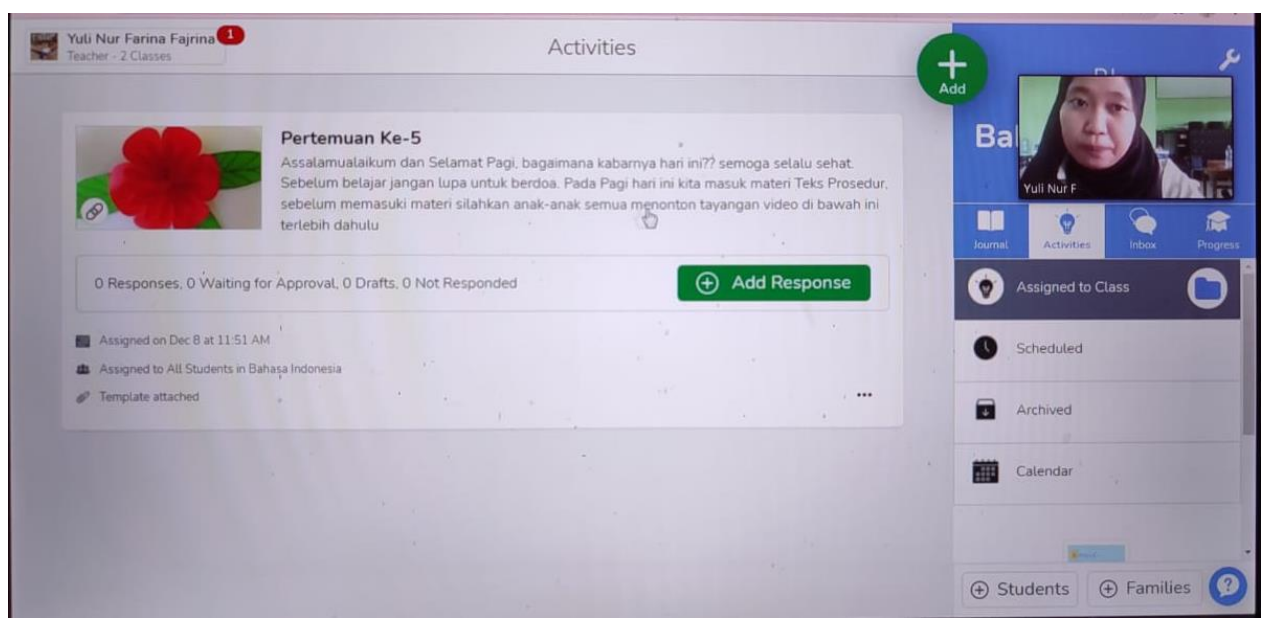

Gambar 8. Seesaw Hasil Kerja Guru

Secara keseluruhan kegiatan pengabdian ini membawa dampak baik yang terlihat dari peningkatan keterampilan guru dalam mengembangkan berbagai jenis media, dan juga mengembangkan bahan evaluasi dan platform virtual classroom berdasarkan website dan platform yang diperkenalkan. Peningkatan ini secara nyata terlihat dari hasil diseminasi dimana guru telah menunjukkan satu persatu hasil karyanya, sekalipun masih ada beberapa kekurangan terutama dalam eksplorasi fitur.

\section{Kesimpulan dan Saran}

Kegiatan pelatihan teknologi pembelajaran yang dilaksanakan dapat memberikan informasi baru bagi guru-guru yang selama ini belum menggunakan platform yang disajikan. Secara umum guru-guru sudah mampu mengikuti tahapan dalam mengoperasikan Pixton, Quizizz dan Seesaw namun belum menggunakan fitur platform tersebut secara lebih mendalam. Kendala yang dialami oleh guru hanya pada jaringan internet yang terkadang tidak stabil ketika hendak melakukan ujicoba. Harapan pada pelaksanaan pengabdian berikutnya adalah praktik yang dilakukan guru dapat terpantau secara keseluruhan sehingga dapat memastikan semua guru tidak mengalami kendala dalam proses penggunaan teknologi pembelajaran. Selain itu, tetap melakukan analisis terlebih dahulu menyesuaikan dengan kebutuhan guru-guru sebagai pelaksana pembelajaran di sekolah.

\section{Ucapan Terimakasih}

Terima kasih kepada Pusat Studi Pendidikan, Kesehatan dan Kesetaraan Gender Lembaga Penelitian dan Pengabdian pada Masyarakat (LPPM) Universitas Borneo Tarakan yang telah memberikan kesempatan kepada kami berupa pendanaan pengabdian melalui dana DIPA Universitas Borneo Tarakan.

\section{Referensi}

Alvarez Jr, A. V. (2020). Learning from the Problems and Challenges in Blended Learning: Basis for Faculty Development and Program Enhancement. Asian Journal of Distance Education, 15(2), 112-132.

Baldwin, S. J., \& Ching, Y. H. (2021). Accessibility in Online Courses: a Review of National and 
Statewide Evaluation Instruments. TecbTrends, 65(5), $\quad$ 731-742. https://doi.org/10.1007/s11528-021-00624-6

Barneva, R. P., Gelsomini, F., Kanev, K., \& Bottoni, P. (2017). Tangible Technology- Enhanced Learning for Improvement of Student Collaboration. Journal of Educational Technology System, O(0), 1-19. https://doi.org/10.1177/0047239517736875

Bogveradze, D., \& Mardaleishvili, T. (2021). Digital Assessment Tools Plickers/ Socrative/ Nearpod/ Seesaw. IRCEELT-2021, 23.

Cabrera, P., Castillo, L., González, P., Quiñónez, A., \& Ochoa, C. (2018). The Impact of Using" Pixton" for Teaching Grammar and Vocabulary in the EFL Ecuadorian Context. Teaching English with Technology, 18(1), 53-76.

Chaiyo, Y., \& Nokham, R. (2017). The effect of Kahoot, Quizizz and Google Forms on the student's perception in the classrooms response system. 2017 International Conference on Digital Arts, Media and Technology (ICDAMT), 178-182.

Deng, L., Shen, Y. W., \& Chan, J. W. W. (2021). Supporting Cross-Cultural Pedagogy with Online Tools: Pedagogical Design and Student Perceptions. TechTrends, 65(5), 760-770. https://doi.org/10.1007/s11528-021-00633-5

Gaby, H. S. (2012). TEAM COMICS. The Participatory Cultures Handbook, 82.

Göksün, D. O., \& Gürsoy, G. (2019). Comparing success and engagement in gamified learning experiences via Kahoot and Quizizz. Computers \& Education, 135, 15-29.

Hofmann, J. (2006). Why Blended learning hasn't (yet) fulfilled its promises. Handbook of Blended Learning: Global Perspectives, Local Designs, 27-40.

Holder, A., \& Mills, B. (2020). Technologies Used by Student Teachers During a Virtual Time. Innovate Learning Summit 2020, 702-706.

Indrawati, C. D. S., \& Octoria, D. (2016). Continuous Professional Development to Improve the Teachers' Competencies. Proceeding The 2nd International Conference On Teacher Training and Education.

Meyers, E. A. (2014). Theory, technology, and creative practice: using pixton comics to teach communication theory. Communication Teacher, 28(1), 32-38.

Mozelius, P. (2017). Problems affecting successful implementation of blended learning in higher education: The teacher perspective. International Journal of Information and Communication Technologies in Education, 6(1), 4-13.

Nasrulloh, I., \& Ismail, A. (2017). Analisis Kebutuhan Pembelajaran Berbasis ICT. Jurnal Petik, $3(1), 28-32$.

Rahman, A. (2021). At the Heart of Teacher Professional Development : Teachers Matter. Indonesian Journal of Learning Education and Counseling, 3(2), 206-220.

Rozitis, C. P. (2017). Instructional design competencies for online high school teachers modifying their own courses. TechTrends, 61, 428-437. https://doi.org/10.1007/s11528-017-0204-2

Stufflebeam, D. L., \& Shinkfield, A. J. (1985). An analysis of alternative approaches to evaluation. In Systematic Evaluation (pp. 45-68). Springer.

Sung, Y., Chang, K., \& Liu, T. (2016). The effects of integrating mobile devices with teaching and learning on students' learning performance : A meta-analysis and research synthesis. Computers \& Education, 94, 252-275. https://doi.org/10.1016/j.compedu.2015.11.008

Tamim, S. R. (2020). Analyzing the Complexities of Online Education Systems: A Systems Thinking Perspective. TechTrends, 64(5), 740-750. https://doi.org/10.1007/s11528-02000538-9

Wong, L., Tatnall, A., \& Burgess, S. (2014). A framework for investigating blended learning effectiveness. Education + Training.

Zhao, F. (2019). Using Quizizz to Integrate Fun Multiplayer Activity in the Accounting Classroom. International Journal of Higher Education, 8(1), 37-43. 